\title{
Non-State Actors, Piracy and Threats to Global Shipping
}

\section{Dirk Siebels}

\section{Introduction}

The relationship between naval forces and commercial shipping companies has long been complicated. Naval operations are hugely different from the day-to-day trading patterns of merchant ships, and few naval officers receive any information about the shipping industry as part of their training.

At the same time, such knowledge is increasingly important for a thorough understanding of the maritime environment. The number of merchant ships will continue to grow in the coming years, yet there are no indications of a similar increase in the number of naval assets. Surveillance capacities can be enhanced by technical assets, ranging from coastal radar stations to unmanned patrol aircraft. Data gathered on specific platforms, however, requires thorough analysis to distinguish irregular events from everyday occurrences, such as trading patterns of merchant ships.

This article shows why the vulnerabilities of commercial shipping should be considered a strategic issue for NATO. The first two sections explain the differences between knowing and understanding how the shipping industry in general and merchant ships in particular conduct day-today operations. The next section looks at the impact of various threats to commercial shipping. Finally, the article underlines why these threats are a strategic concern for NATO navies and explains the limited amount of interaction between them and the global merchant fleet.

\section{MSA and MDA-differences between knowledge and insights}

Knowing and understanding what happens at sea is crucial for NATO as well as for most of its member states. Maritime connections across the North Atlantic are the backbone of the alliance, and NATO forces are frequently involved in maritime operations. Given the sheer number of vessels that are part of the commercial shipping industry, it seems obvious 
that naval officers should know at least the basic details about their operations.

There is, however, a considerable difference between mere knowledge and actual understanding. This can be highlighted by differences between maritime situational awareness (MSA) and maritime domain awareness (MDA). Both terms are sometimes used as synonyms, largely due to the fact that many organisations use their own definitions for MSA or MDA.

Arguably the most relevant definition for maritime domain awareness has been provided by the International Maritime Organization (IMO), the United Nations agency responsible for the safety and security of global shipping. The IMO defines MDA as the 'effective understanding of anything associated with the maritime domain that could impact security, safety, the economy or the marine environment'. ${ }^{1}$

Before reaching an 'effective understanding', it is necessary to know as much as possible about what is actually happening at sea. Where are ships located, where have they come from and where are they going? Are their movements completely normal or is it possible to identify suspicious patterns? Finding answers to such questions requires a good level of MSA which combines different technical platforms. Merchant ships, for example, can be tracked through their AIS signals, coastal radar stations or space-based surveillance systems.

Not every country is able to employ the same structure. Nevertheless, the basic principle remains the same: MSA means knowing as much as possible about what is happening at sea. Raw data must then be analysed and assessed to understand these events and therefore to reach a good level of MDA. Given the sheer number of vessels that are operating in many regions around the globe, MSA is already a formidable challenge for national authorities. It is simply impossible to know everything about the movements of local cargo ships, small fishing vessels or pleasure craft at the same time.

From a NATO point of view, however, these smaller vessel types are only relevant for specific operations in a particular region. It is much more important to have an understanding of commercial vessels in international trade. According to the United Nations Conference on Trade and Development, more than 98,000 such ships were registered around the world in

1 International Maritime Organization, "Enhancing maritime domain awareness in West Indian Ocean and Gulf of Aden”, IMO Latest News, 14 November 2018, https: //imo.org/en/MediaCentre/Pages/WhatsNew-1203.aspx. 
2020, an increase of more than eight per cent since $2015 .^{2}$ By comparison, the US Navy currently plans to have 355 ships in active service by $2034,{ }^{3}$ yet there are already questions around potential personnel shortages. Moreover, naval planners have to take into account that only 30 to 40 per cent of all vessels are operational at any given time, a significant difference from commercial ships, which have a much higher operational availability.

\section{Understanding the shipping industry}

Knowing details about the actual number of commercial ships is not enough. Understanding at least some basic details about commercial shipping is equally important. That is highlighted by the role of NATO and individual member states in counter-piracy operations or the enforcement of arms embargoes, as well as by the day-to-day analysis of events in areas of strategic interest for the alliance.

Unfortunately, many naval officers tend to look at the 'shipping industry' as one coherent actor. This view fails to acknowledge vast differences between publicly listed companies operating hundreds of vessels and family-owned businesses which own just a handful of tankers or bulk carriers. It also fails to take different types of companies into account. Some shipping companies own and operate their ships, other owners merely use them as a financial investment and rely on specialised ship managers.

These are just some aspects that are vital for an understanding of the shipping industry overall and the challenges that industry stakeholders are facing. Furthermore, different tiers can be identified as some shipping companies are much keener to avoid security threats than others. That is underlined by the fact that many commercial ships in the Indian Ocean or the Gulf of Guinea still operate without visible security measures, which

2 UNCTAD Stat, "Merchant fleet by flag of registration and by type of ship, annual Number of ships", accessed 14 January 2021, https://unctadstat.unctad.org/wds/Ta bleViewer/tableView.aspx?ReportId=93 (figures include merchant ships of 100 gross tons and above).

3 David B. Larter, "In a quest for 355 ships, US Navy leaders are unwilling to accept a hollow force", Defense News, 13 January 2020, https://www.defensenews.com/dig ital-show-dailies/surface-navy-association/2020/01/13/in-a-quest-for-355-ships-us-nav y-leaders-are-unwilling-to-accept-a-hollow-force/. 
are recommended as best management practices by industry organisations. ${ }^{4}$

Achieving a better understanding of commercial shipping would help NATO's naval forces to enhance MDA. This would provide an extremely useful background for politicians and strategic planners to determine which capabilities are required in the medium to long term, and to execute specific operations in the short term. When it comes to enforcing an embargo, for example, it is vital to understand the normal patterns of maritime traffic in the respective region. It is then possible to identify irregular patterns that should be investigated further, possibly even leading to examples of opposed boarding of non-compliant merchant vessels.

\section{Commercial shipping faces different types of threats}

The previous section has outlined some benefits of a better grasp of commercial realities in the shipping industry for NATO's own operations. At the same time, such insights would help NATO to recognise and address certain vulnerabilities of commercial shipping. In the past, these have often been ignored as NATO members have concentrated on core naval tasks. More recently, however, threats to commercial shipping and to the security of vital shipping routes have developed into more strategic concerns.

Operation Ocean Shield, aimed at countering Somalia-based piracy, was arguably the first large-scale NATO operation largely aimed at protecting commercial shipping. Many NATO members contributed naval assets to the operation between 2009 and 2016. Another NATO operation (Unified Protector), conducted in 2011, was aimed at enforcing the arms embargo around Libya during the civil war in the country. To address concerns from shipping industry organisations, NATO representatives stressed that

4 At the time of writing (January 2021), the most recent guidance documents were "BMP5: Best Management Practices to Deter Piracy and Enhance Maritime Security in the Red Sea, Gulf of Aden, Indian Ocean and Arabian Sea" for operations in the western Indian Ocean (https://www.maritimeglobalsecurity.org/media/1038/b mp5-high_res.pdf) and "BMP West Africa: Best Management Practices to Deter Piracy and Enhance Maritime Security off the Coast of West Africa including the Gulf of Guinea" for operations off West and Central Africa (https://www.maritime globalsecurity.org/media/1047/bmp-wa-hi-res.pdf). 
they were 'working to ensure that shipping in the Mediterranean $[. .$.$] is not$ disrupted'.$^{5}$

While cooperation between shipping companies and naval forces-both on the national and the NATO level-has somewhat improved in the recent past, the relationship remains arduous. Industry organisations tend to present themselves as speaking for the entire shipping industry, even though they generally represent the interests of a specific subset of owners and operators. Finding common ground for discussions is therefore often complicated.

Even when commercial shipping operations are subject to specific threats, these may have distinctive implications on the company level. Some shipping companies, for example, have been deterred by insecurity in Libya and have refused to call at Libyan ports and terminals since the fall of the Gaddafi regime in 2011. For other companies, however, relatively high-risk levels have created business opportunities, allowing them to charge higher rates from charterers which were more than enough to cover the costs of specific mitigation measures.

Some merchant vessels have even been involved in illegal fuel imports or other types of smuggling to ports in Libya. By and large, these ships are not operated by reputable companies. Nevertheless, they are part of the shipping industry, indicating once again that it is not merely one monolithic actor.

The situation in other countries and regions is similar. Many shipping companies may be subject to threats, while others are complicit in illicit operations. Unauthorised fuel transfers at sea or illegal transshipments of catches from industrial fishing vessels to refrigerated cargo ships are two prominent examples. These are particularly likely to occur where coastal countries have limited capacities to enforce laws and regulations at sea.

Overall, the complicated web of actors in the private sector makes discussions about different types of threats and how they affect commercial shipping complicated. After all, industry organisations often present contrasting opinions and suggestions which are largely based on their membership structure. For example, the Baltic and International Maritime Council (BIMCO) is 'the world's largest direct-membership organisation for shipowners, charterers, shipbrokers and agents'. ${ }^{6}$ Nevertheless, BIMCO

5 NATO, "NATO to Minimize Impact of Libyan Operation on Merchant Shipping", Offshore Energy, 23 June 2011, https:/www.offshore-energy.biz/nato-to-minimize-i mpact-of-libyan-operation-on-merchant-shipping/.

6 BIMCO, "About us and our members", accessed 14 January 2021, https://www.bim co.org/about-us-and-our-members. 
only represents around $60 \%$ of the world's merchant fleet, which is measured by deadweight tonnage.

The International Chamber of Shipping (ICS) is even larger, representing more than $80 \%$ of commercial ships worldwide. However, ICS membership 'comprises national shipowners' associations ${ }^{17}$ rather than individual companies. Other industry organisations have less diverse membership. Examples include OCIMF or Intertanko, which both focus on specific segments of tanker owners, or Intercargo, which represents shipping companies that own bulk carriers.

Furthermore, naval officers must realise that there are virtually no existential security threats to commercial shipping overall, even though they may be significant for specific types of infrastructure, e.g. crude oil and LNG terminals, or individual companies. Somalia-based piracy provides a perfect example. Frequent hijackings of merchant ships were often described as a threat to 'freedom of navigation and the flow of commerce'. ${ }^{8}$ At the same time, even at the height of Somali piracy between 2009 and 2011, thousands of ships continued to sail through the western part of the Indian Ocean every year, and commercial shipping in the area was far from coming to a standstill. The same has been true for other regions with substantial numbers of recorded piracy attacks, such as parts of South East Asia or the Gulf of Guinea.

Piracy, however, represents merely one type of security threat to commercial shipping, namely those that are driven by profits. It is comparatively easy to identify drivers behind such threats and implement mitigation measures to minimise the risk. Other threats, such as potential attacks by terrorist or state-affiliated groups, are another factor to consider. More often than not, the probability of such incidents occurring is very low. Nevertheless, the risk level may be notable due to the potentially severe consequences-merchant ships are simply not constructed to withstand

7 International Chamber of Shipping, "About ICS", accessed 14 January 2021, https:/ /www.ics-shipping.org/about-ics/.

8 James Caponiti, "The Ongoing Piracy Problem in the Waters off of Somalia", U.S. Department of Transportation, 5 May 2009, https://www.transportation.gov/testim ony/ongoing-piracy-problem-waters-somalia. 
the impact of waterborne improvised explosive devices ${ }^{9}$ or limpet mines attached to the hull ${ }^{10}$.

As mentioned above, even high-risk levels are generally not enough to deter all commercial shipping. Some companies may in fact be attracted by profitable opportunities that arise when others avoid a specific region altogether. This often seems counter-intuitive to naval officers, yet it is a reality in the private sector.

Aside from physical security threats, potential cybersecurity breaches have also received a lot of attention in recent years. While the actual threats are new and constantly developing, the underlying structure with which to assess and mitigate the associated risks remains the same. Moreover, similar to more traditional threats, cyberattacks are not an existential threat to commercial shipping overall, even though that may look very different for both individual companies and operators of infrastructure such as ports or specific terminals.

Much has been made of scenarios that involve hackers obtaining information about valuable cargoes before sending 'traditional pirates to board the vessel (...) and locate what they are looking for' ${ }^{11}$ However, there is no evidence behind this or similar headline-grabbing warnings. And when 'you begin to dig into the logistics of such a criminal enterprise, it quickly falls apart'. ${ }^{12}$ It would be much more important to gather information about actual attacks to identify trends, the motivations of different actors as well as potential vulnerabilities. However, most organisations have very little interest in sharing information about actual or even attempted attacks until there is a major impact, ${ }^{13}$ a problem that the maritime sector has in common with virtually all other sectors.

9 "Anatomy of a 'drone boat'", Conflict Armament Research, December 2017, https://www.conflictarm.com/perspectives/anatomy-of-a-drone-boat/.

10 Sandra Petersmann, "Tanker attacks in the Gulf — evidence or warmongering?", Deutsche Welle, 21 June 2019, https:/www.dw.com/en/tanker-attacks-in-the-gulf-e vidence-or-warmongering/a-49295596.

11 Nicholas Newman, "Cyber pirates terrorising the high seas", Engineering \& Technology, 18 April 2019, https://eandt.theiet.org/content/articles/2019/04/cyber-pirat es-terrorising-the-high-seas/.

12 David Rider, "Maritime meets cyber security", The Maritime Executive, 16 October 2019, https:/www.maritime-executive.com/blog/maritime-meets-cyber-security.

13 This was highlighted, for example, during a cyber security conference in 2019, held at the NATO Maritime Interdiction Operational Training Centre. A comprehensive summary of the conference can be found at: https://nmiotc.nato.int/wp-c ontent/uploads/2020/01/3000-NSC-74_NU120_02-08-19_NMIOTC-2019-cyber-sec urity-FFT-Paper.pdf. 
Strategic issue for NATO?

The previous sections have shown that a good understanding of commercial shipping is vital for navies to achieve comprehensive maritime domain awareness. At the same time, day-to-day operations in the private sector are considerably different from those conducted by navies, making it hard for naval officers to understand how particular threats affect commercial shipping.

Whether-and how-maritime crime should be reflected in strategic documents and thinking is therefore a far-reaching question. Moreover, it is far from easy to conceptualise criminal activities in the maritime environment. One recently published article ${ }^{14}$ has attempted to introduce the concept of 'blue crime' to cover various illegal activities at sea. Despite the catchy title, the authors failed to provide a theoretical foundation for their ideas. Nevertheless, it is vital to recognise intersections between a broad array of criminal activities, both on land and at sea. These are crucial for a thorough analysis of specific crimes and an evaluation of their relevance for commercial shipping.

As explained above, not even a large number of pirate attacks in a strategically important region such as the western Indian Ocean constitutes an existential threat to overall shipping operations. However, maritime trade is irreplaceable, even for landlocked countries. Within NATO, this is often acknowledged in discussions related to maritime security, meaning that 'the maritime domain is of strategic importance for NATO'15. In the context of specific threats to commercial shipping, the crucial role of secure shipping routes - and other maritime infrastructure-provides a powerful political argument, for example during debates on the future role of navies.

From an operational point of view, threats to commercial shipping may be linked to other maritime security issues, yet they are generally regionspecific. Even threats such as smuggling or illegal, unreported and unregulated fishing — which are issues for many governments worldwide-have to be addressed in specific ways. Regional resources and capacities are not the same everywhere. Joint operations or other forms of partnerships be-

14 Christian Bueger and Timothy Edmunds, "Blue crime, Conceptualising transnational organised crime at sea", Marine Policy, vol. 119 (September 2020).

15 NATO, "NATO's maritime activities", accessed 14 January 2021, https://www.nat o.int/cps/en/natohq/topics_70759.htm. 
tween regional and NATO navies can therefore not fit into a one-size-fitsall blueprint.

On the part of the alliance, it is extremely useful to understand patterns of life in defined regions and how these relate to commercial shipping. That involves direct attacks against merchant ships, but also other illicit activities and whether these are linked to specific threats. Building up such knowledge over time provides a foundation for future operations in each respective area, even if no such operations are expected to occur. The development of Somali piracy from an issue with mainly local impacts to an escalating threat to merchant ships in international trade within a few months is a classic example of a situation that required a quick response.

Areas of strategic concern to NATO, such as the Mediterranean or the North Atlantic, should be analysts' main focus. However, the global nature of commercial shipping means that it is useful to monitor other parts of the world where shipping companies face security threats. That includes regions such as South America or South East Asia, but also the Gulf of Guinea, which has received a lot of media and political attention in the recent past due to increasing concerns about kidnappings of seafarers from ships in that region.

NATO does not have a strategic interest in either of these regions, yet it is useful to remain up-to-date with threat developments as these could occur in a similar form elsewhere. That includes diverse-and non-traditional-security threats with potential impacts on commercial operations, ranging from irregular migration on maritime routes to spoofing of navigational systems. Regional responses to such threats may not be easily transferable to other areas. However, they can provide valuable lessons and case studies.

\section{Links between NATO and commercial shipping}

While links between NATO and the shipping industry must become closer to address the concerns mentioned above, the fundamental infrastructure has long been in place. For example, the NATO Shipping Centre is the 'primary point of contact for the exchange of merchant shipping information between NATO's military authorities and the international shipping community'. ${ }^{16}$ In practice, links are also strengthened by frequent exercises

16 NATO Shipping Centre, "About", accessed 14 January 2021, https://shipping.nato .int/nsc/about. 
for NCAGS ${ }^{17}$ personnel, allowing merchant navy officers to serve as naval officers for short periods.

Unfortunately, interactions between navies and the private sector in the maritime environment remain limited. Both on the personal and the institutional level, this often leads to a lack of knowledge about broader industry concerns and even about seemingly basic issues such as differences in trading patterns for various types of vessels.

Such problems are regularly pointed out in discussions between naval officers and industry representatives. In the past, this has complicated dayto-day interactions, for example efforts to counter Somali piracy. Almost from the beginning of the NATO operation in the Indian Ocean, the alliance offered protection for convoys of merchant vessels, 'only to realise that operators would rather run the risk of a pirate attack than losing money by having their ships spend more time at sea'.18

In the context of this particular operation, coordination was addressed by dedicated meetings and reporting centres. However, the overall lack of ongoing cooperation remains an issue, exacerbated by frequent personnel changes on the military side. Officers rarely stay in a particular post for more than three years and for an even shorter time in an operation. It is therefore vital to improve institutionalised cooperation between NATO navies and the shipping industry.

Officer exchanges, which are common practice between navies, are one potential way to achieve this. In addition, the curriculum of relevant courses should be updated to include at least some lectures about the operations of shipping companies in general and merchant vessels in particular. These will not be enough to turn naval personnel into experts on commercial shipping, yet such lessons would allow for more lateral thinking about security challenges at sea and their potential impact.

17 The abbreviation stands for Naval Cooperation and Guidance for Shipping. NCAGS is supposed to be an interface between commercial shipping companies and navies; the NATO Shipping Centre provides a comprehensive introduction to the concept: "NCAGS Guide to Owners, Operators, Masters and Officers", accessed 14 January 2021, https://shipping.nato.int/nsc/page14865015.aspx.

18 Dirk Siebels, Maritime Security in East and West Africa: A Tale of Two Regions (London: Palgrave Macmillan, 2020), 5. 


\section{Summary}

Monitoring commercial shipping is a key part of maritime situational awareness. Any comprehensive analysis also requires knowledge of regular trading patterns, as well as an understanding of specific threats and their impacts on these patterns. Vulnerabilities of commercial shipping operations are therefore an issue that should receive more attention from NATO navies.

Furthermore, navies throughout the alliance are already having to deal with an increasing number of constabulary tasks on top of their traditional roles and operations. At the same time, governments around the world are facing revenue shortfalls and have shifted their spending priorities due to the economic impact of measures to curb the spread of Covid-19. Naval planners are therefore having to provide additional arguments to secure funding for operational and procurement budgets.

By and large, security is unlikely to be perceived as an end in itself by politicians. Justifying a relatively expensive navy will be much easier when the navy's role in combating maritime security concerns can be highlighted. In this context, commercial shipping is a vital recipient which benefits from better governance and law enforcement capacities at sea.

This has been underlined by the industry's willingness to cooperate and coordinate activities with naval forces when faced with concrete threats, e.g. piracy off Somalia or in South East Asia. Any shipping company has to earn money while also fulfilling its duty of care obligations towards the crews on their ships. Piracy-as well as other maritime security threatshas an impact on both aspects, creating an incentive for shipping companies to engage directly with navies and other maritime security agencies. Over the past decade, various engagements have helped to build trust on both sides, helping to establish longer-term cooperation instead of ad-hoc groups with the sole aim of reducing specific types of threats within a short time frame.

\section{Works cited}

Bueger, Christian, and Edmunds, Timothy. "Blue crime, Conceptualising transnational organised crime at sea." Marine Policy, vol. 119 (September 2020).

Caponiti, James. "The Ongoing Piracy Problem in the Waters off of Somalia." U.S. Department of Transportation, 5 May 2009. https://www.transportation.gov/testi mony/ongoing-piracy-problem-waters-somalia. 
Conflict Armament Research. "Anatomy of a 'drone boat'." December 2017. https:/ /www.conflictarm.com/perspectives/anatomy-of-a-drone-boat/.

International Maritime Organization. "Enhancing maritime domain awareness in West Indian Ocean and Gulf of Aden." IMO Latest News, 14 November 2018. https://imo.org/en/MediaCentre/Pages/WhatsNew-1203.aspx.

Larter, David B. "In a quest for 355 ships, US Navy leaders are unwilling to accept a hollow force." Defense News, 13 January 2020. https://www.defensenews.com/di gital-show-dailies/surface-navy-association/2020/01/13/in-a-quest-for-355-ships-usnavy-leaders-are-unwilling-to-accept-a-hollow-force/.

NATO. "NATO to Minimize Impact of Libyan Operation on Merchant Shipping." Offshore Energy, 23 June 2011. https:/www.offshore-energy.biz/nato-to-minimiz e-impact-of-libyan-operation-on-merchant-shipping/.

Newman, Nicholas. "Cyber pirates terrorising the high seas." Engineering \& Technology, 18 April 2019. https://eandt.theiet.org/content/articles/2019/04/cyber-pira tes-terrorising-the-high-seas/.

Petersmann, Sandra. "Tanker attacks in the Gulf — evidence or warmongering?" Deutsche Welle, 21 June 2019. https://www.dw.com/en/tanker-attacks-in-the-gulfevidence-or-warmongering/a-49295596.

Rider, David. "Maritime meets cyber security." The Maritime Executive, 16 October 2019. https:/www.maritime-executive.com/blog/maritime-meets-cyber-security.

Siebels, Dirk. Maritime Security in East and West Africa: A Tale of Two Regions. London: Palgrave Macmillan, 2020. 